\title{
Low sequence variation among isolates of infectious hypodermal and hematopoietic necrosis virus (IHHNV) originating from Hawaii and the Americas
}

\author{
Kathy F. J. Tang*, Donald V. Lightner \\ Department of Veterinary Science and Microbiology, University of Arizona, Tucson, Arizona 85721, USA
}

\begin{abstract}
A $2.9 \mathrm{~kb}$ fragment of the infectious hypodermal and hematopoietic necrosis virus (IHHNV) genome, which contains the coding sequence of putative non-structural and capsid proteins, was amplified and sequenced from each of $14 \mathrm{IHHNV}$ isolates collected from cultured penaeid shrimp stocks in Hawaii and various sites in the Americas between 1982 and 1997. The sequence comparison indicates that the IHHNV genome is very stable, with 99.6 to $100 \%$ similarity among these 14 isolates. Only nucleotide substitutions were found. The percentage of substitution was higher in the putative capsid proteins region $(1.3 \%)$ than in the putative non-structural proteins region $(0.6 \%)$. Out of 25 substitutions found, 14 resulted in amino acid changes. There is no apparent association between clinical outcomes and particular amino acid substitutions. Based on genetic distances, the isolates were clustered into 3 groups that generally correspond with their geographic origins.
\end{abstract}

KEY WORDS: Shrimp virus - Infectious hypodermal and hematopoietic necrosis virus - IHHNV · Sequence variation

Resale or republication not permitted without written consent of the publisher

\section{INTRODUCTION}

Infectious hypodermal and hematopoietic necrosis virus (IHHNV) is an important cause of disease in cultured penaeid shrimp. This virus was first detected in juvenile Penaeus stylirostris (taxonomy used is according to Holthuis 1980) cultured in Hawaii in 1981 (Lightner et al. 1983a,b), where it caused up to $90 \%$ mortalities. Since then, this virus has been detected in other life stages of a number of penaeids collected from the Americas, Oceania, and Asia (Lightner 1996, Flegel 1997).

IHHNV is a small, icosahedral, non-enveloped virus containing a single-stranded linear DNA genome of approximately $4.1 \mathrm{~kb}$ in length (Bonami et al. 1990, Mari et al. 1993). Based on size, morphology, and biochemical structure, IHHNV is considered to be a member of

*E-mail: fengjyu@u.arizona.edu the family Parvoviridae (Bonami et al. 1990). Nearly $100 \%$ of the IHHNV genome sequence and its 3 large open reading frames (ORF1, 2, 3) have been determined (Nunan et al. 2000, Shike et al. 2000). Among them, ORF1 represents approximately $50 \%$ of the genome and may encode a 666 amino acid polypeptide; this is predicted to be a non-structural protein 1 (NS1) based upon its degree of homology with 2 mosquito brevidensoviruses. ORF2 starts at 56 nucleotides upstream of ORF1 and overlaps with ORF1. It could encode a 343 amino acid polypeptide, a putative nonstructural protein 2 (NS2). ORF3 also overlaps (59 nucleotides) with ORF1, and could encode a 329 amino acid polypeptide. At least 4 structural proteins, 74, 47, 39 , and $37.5 \mathrm{kDa}$ in size, are found in the purified virions (Bonami et al. 1990). The $47 \mathrm{kDa}$ protein was found to be derived from ORF3 based on partial amino acid sequencing (Poulos \& Lightner unpubl. data); it is likely that ORF3 encodes viral structural proteins. 
Although IHHNV was reported to be extremely virulent towards Penaeus stylirostris during the early 1980s, in recent years there has been an apparent decrease in IHHNV-related mortality in stock of $P$. stylirostris (Morales-Covarrubias et al. 1999). One possible reason for this reduction in virulence is that the IHHNV genome has changed. Hence, in this study, we analyzed $70 \%$ of the IHHNV genome from 14 isolates that were collected during 1982 to 1997 to determine if there have been changes in the viral genome. The results demonstrate that the sequence variation from the earliest isolates to the recent ones is very low, and there is no apparent association between the decrease in virulence of IHHNV and particular nucleotide substitutions.

\section{MATERIALS AND METHODS}

IHHNV-infected shrimp samples, obtained from various regions between 1982 and 1997 (Table 1), were stored frozen in the archive collection at the University of Arizona. The total DNA was extracted from tissues of infected shrimp (either pleopods or head soft tissue) with a high pure PCR template preparation kit (Roche Molecular Biochemicals). The PCR was carried out in a $50 \mu \mathrm{l}$ reaction containing PCR buffer $(10 \mathrm{mM}$ Tris- $\mathrm{HCl}$, $\left.\mathrm{pH} 8.85,25 \mathrm{mM} \mathrm{KCl}, 5 \mathrm{mM}\left(\mathrm{NH}_{4}\right)_{2} \mathrm{SO}_{4}, 2 \mathrm{mM} \mathrm{MgSO}_{4}\right)$, dNTPs $(0.2 \mu \mathrm{M}$ each), primers $(0.3 \mu \mathrm{M}$ each), $2.5 \mathrm{U}$ of Pwo DNA polymerase (Roche Molecular Biochemicals), and $2 \mu \mathrm{l}$ of extracted DNA sample. Following denaturation for $2 \mathrm{~min}$ at $94^{\circ} \mathrm{C}, 35$ cycles of $30 \mathrm{~s}$ at $94^{\circ} \mathrm{C}, 30 \mathrm{~s}$ at $55^{\circ} \mathrm{C}, 2 \mathrm{~min}$ at $72^{\circ} \mathrm{C}$, with a final extension at $72^{\circ} \mathrm{C}$ for $7 \mathrm{~min}$, Primers IHHNV721F (5'-TCT ACT GCC TCT GCA ACG AG-3') and IHHNV2860R (5'GTG GGT CTG GTC CAC TTG AT-3') were used to

Table 1. Year, source and related information about the infectious hypodermal and hematopoietic necrosis virus (IHHNV) isolates collected from Penaeus spp. and used in this study. A: adult; SA: sub-adult; J: juvenile; +/-: occurrence/ absence of mortality in the infected shrimp

\begin{tabular}{|c|c|c|c|c|c|c|}
\hline Case no. & Year & Species & Origin & Location & Stage & Mortality \\
\hline 1 & 1982 & P. stylirostris & Hawaii & Farm & $\mathrm{J}$ & + \\
\hline 2 & 1987 & P. stylirostris & Hawaii & Farm & SA & + \\
\hline 3 & 1991 & P. vannamei & Hawaii & Farm & $\mathrm{J}$ & - \\
\hline 4 & 1991 & P. vannamei & Hawaii & Farm & $\mathrm{J}$ & - \\
\hline 5 & 1990 & P. stylirostris & Mexico & Farm & $\mathrm{J}$ & - \\
\hline 6 & 1991 & P. stylirostris & Mexico & Wild & A & - \\
\hline 7 & 1995 & P. stylirostris & Mexico & Wild & A & - \\
\hline 8 & 1996 & P. stylirostris & Mexico & Wild & SA & - \\
\hline 9 & 1995 & P. stylirostris & Guam (Mexico) & Hatchery & $\mathrm{J}$ & - \\
\hline 10 & 1990 & P. vannamei & Colombia & Unknown & $\mathrm{J}$ & - \\
\hline 11 & 1992 & P. stylirostris & Ecuador & Unknown & SA & - \\
\hline 12 & 1997 & P. vannamei & Panama & Farm & $\mathrm{J}$ & - \\
\hline 13 & 1991 & P. vannamei & Texas & Farm & SA & - \\
\hline 14 & 1993 & P. vannamei & Texas & Farm & A & - \\
\hline
\end{tabular}

amplify a $2.0 \mathrm{~kb}$ fragment from Nucleotides 721 to 2860, and Primers IHHNVF (5'-ATG TGC GCC GAT TCA ACA AG-3') and IHHNVR1 (5'-CTA AGT GAC GGC GGA CAA TA-3') were used to amplify a $1.2 \mathrm{~kb}$ fragment from Nucleotide 2758 to 4001 . All nucleotide positions refer to the published IHHNV sequence (GenBank Accession No. AF218266).

The amplified products were directly sequenced with an automated Applied Biosystems 3700 DNA sequencer at the sequencing facility of the University of Arizona. A sequence of $2.9 \mathrm{~kb}$ from Nucleotides 816 to 3744 was compared among these 14 IHHNV isolates. Multiple nucleotide-sequence alignment and phylogenetic analysis were performed with the Clustal X (Thompson et al. 1997) software package (Version 1.8). The phylogenetic tree was calculated with the neighbor-joining (NJ) method under the principle of minimum evolution (Saitou \& Nei 1987). Boostrap NJ command $(\mathrm{N}=1000)$ was used to generate a boot strapped tree. Bootstrap values greater than $70 \%$ were considered to be related with a significance of $95 \%$ (Hills \& Bull 1993). For PAUP (in Wisconsin Package, Genetics Computer Group) analysis, the heuristic algorithm was used for the maximum-parsimony analysis. The data were re-sampled by 100 bootstrap replicates.

\section{RESULTS AND DISCUSSION}

The origins, hosts, and clinical presentations of the 14 IHHNV isolates used in this study are listed in Table 1. Case 1 was Penaeus stylirostris collected from a farm in Oahu, Hawaii. The IHHNV isolate from this case was highly virulent and caused nearly $100 \%$ mortality. Case 2 was P. stylirostris from the same farm in Oahu during 1987. Cases 3 and 4 were IHHNV-infected $P$. vannamei collected from farms in Oahu and Moloki, Hawaii, respectively. These shrimp did not show mortalities but had symptomatic runt-deformity syndrome (Kalagayan et al. 1991). Samples from Cases 5 to 8 were $P$. stylirostris collected from Mexico; the juveniles in Case 5 were obtained from a farm north of the Gulf of California; the wild stocks (Cases 6 to 8) were caught in the Gulf of California, the exact collection sites are not known. Samples from Case 9 were juvenile $P$. stylirostris collected from a hatchery on Guam, where the stock was imported originally from Mexico. Samples of Cases 10 to 12 (P. vannamei and $P$. stylirostris) were ob- 
Table 2. IHHNV isolates from Penaeus spp. Amino acid changes in putative non-structural proteins 1, 2 and capsid proteins; numbers in parentheses: nucleotide position in IHHNV genome (GenBank Accession No. AF218266). Consensus is indicated by dashes, while those that differ are indicated. Con: consensus amino acid; ORF: open reading frame

\begin{tabular}{|c|c|c|c|c|c|c|c|c|c|c|c|c|c|c|c|}
\hline Amino acid no. & Con & 1 & 2 & 3 & 4 & 5 & 6 & 7 & 8 & 9 & 10 & 11 & 12 & 13 & 14 \\
\hline $14^{\mathrm{a}}(855)$ & $\mathrm{E}$ & - & - & - & - & - & - & - & - & K & - & - & - & - & - \\
\hline $151^{a}(1267)$ & $\mathrm{R}$ & - & - & - & - & - & - & - & - & Q & - & - & - & - & - \\
\hline $161^{\mathrm{a}}(1296)$ & $\mathrm{T}$ & - & - & - & - & - & - & - & - & - & $\mathrm{S}$ & - & - & - & - \\
\hline $165^{\mathrm{a}}(1308)$ & $\mathrm{G}$ & - & - & - & - & $\mathrm{S}$ & - & $\mathrm{S}$ & - & - & - & - & - & - & - \\
\hline $357^{a}(1885)$ & $\mathrm{E}$ & - & - & - & - & A & - & A & - & - & - & - & - & - & - \\
\hline $642^{\mathrm{a}}(2741)$ & $\mathrm{D}$ & - & - & - & - & - & - & - & - & - & - & - & - & - & E \\
\hline $646^{\mathrm{a}}(2751)$ & $\mathrm{D}$ & - & - & - & - & - & - & - & - & - & $\mathrm{N}$ & - & - & - & - \\
\hline $170^{\mathrm{b}}(1267)$ & $\mathrm{E}$ & - & - & - & - & - & - & - & - & $\mathrm{K}$ & - & - & - & - & - \\
\hline $58^{\mathrm{c}}(2930)$ & F & - & - & - & - & - & - & - & - & - & $\mathrm{L}$ & - & - & - & - \\
\hline $105^{\mathrm{c}}(3070)$ & M & - & - & - & - & - & - & - & - & - & - & - & - & $\mathrm{L}$ & - \\
\hline $113^{\mathrm{C}}(3095)$ & V & - & - & - & - & - & - & - & - & - & - & - & $\mathrm{A}$ & - & - \\
\hline $138^{\mathrm{c}}(3169)$ & $\mathrm{F}$ & - & - & - & - & - & - & - & - & - & - & - & I & - & - \\
\hline $240^{\mathrm{C}}(3475)$ & L & - & - & - & - & I & I & I & I & - & - & - & - & - & - \\
\hline $241^{\mathrm{c}}(3478)$ & $\mathrm{K}$ & - & - & - & - & - & - & - & Q & Q & - & - & - & - & - \\
\hline $303^{c}(3664)$ & $\mathrm{V}$ & - & - & - & - & - & - & - & - & - & $\mathrm{T}$ & $\mathrm{T}$ & $\mathrm{T}$ & - & $\mathrm{T}$ \\
\hline
\end{tabular}

tained from 3 different countries in Central/South America. Cases 13 and 14 (P. vannamei) were sent to us in 1991 and 1993 from a shrimp farm in Texas, and the origins of the shrimp before importation to Texas are not known, although they are suspected to have come from Hawaii and Ecuador, respectively, based on information provided by the farmer.

The sequence within the $2.9 \mathrm{~kb}$ region among these isolates showed 25 nucleotide substitutions; no deletions or insertions were detected. There were 12 substitutions in ORF1 (Nucleotides 816 to 2816), 5 substitutions in ORF2 (Nucleotides 760 to 1851) and 13 within ORF3 (Nucleotides 2758 to 3747 ). The nucleotide sequence similarity among isolates is between 99.6 and $100 \%$. The degree of variation is rather low compared to that reported for human parvovirus B19 (up to $4 \%$; Erdman et al. 1996).

Although the non-structural protein is conserved, nucleotide substitution could still occur from selection pressure as a result of its essential enzymatic functions. A difference of 12 substituted nucleotides within 2001 nucleotides $(0.6 \%)$ was found in ORF1, and 13 substituted nucleotides within 990 nucleotides (1.3\%) was found for the ORF3 region. ORF2 had the lowest difference at $0.4 \%$ (5 substituted nucleotides within 1092 nucleotides). The relative level of variation is similar to that found in vertebrate parvoviruses, which also have a higher percentage of nucleotide substitutions in the capsid proteins than in the non-structural proteins (Truyen et al. 1995, Hemauer et al. 1996).

For the IHHNV isolates in this study, there were $7 \mathrm{nu}$ cleotide substitutions that resulted in changes of amino acids in ORF1; the other 5 base changes were silent. For ORF2, only 1 nucleotide substitution resulted in a change of amino acid, 13 out of the 14 cases had identical amino acid sequences; in Case 9, there was a difference in a single amino acid: amino acid 170 is lysine instead of glutamic acid. For ORF3, 6 of the base changes were silent, and there were 7 amino acid changes (Table 2).

Change in pathogenicity of some parvoviruses has been associated with amino acid change in the capsid proteins (Tijssen et al. 1995, Fox et al. 1999), although in other cases no such association was found (Gallinella et al. 1995, Erdman et al. 1996). To examine this possibility for the IHHNV isolates, we compared the translated amino acid sequence of ORF3 isolated from shrimp showing mortalities (Cases 1 and 2) and those from shrimp of the same species with asymptomatic infections (Cases 5 to 9, and 11), but we were unable to detect any consistent profile of amino acid changes that correlated with virulence (Table 2). In the comparison of Cases 1 and 6, both were IHHNVinfected Penaeus stylirostris; the virus from Case 1 was extremely virulent, while the virus from Case 6 did not cause mortality in the infected shrimp. In these cases, the translated amino acid sequences of ORF1 and ORF2 were the same, and there was only 1 amino acid difference in the translated amino acid sequence from ORF3. The change was from leucine to isoleucine at amino acid 240. The change from leucine to isoleucine seems to be conservative, because both are non-polar amino acids with identical molecular weights.

The sequence variation between the isolates studied was very low, but phylogenetic analyses of $2.9 \mathrm{~kb}$ 


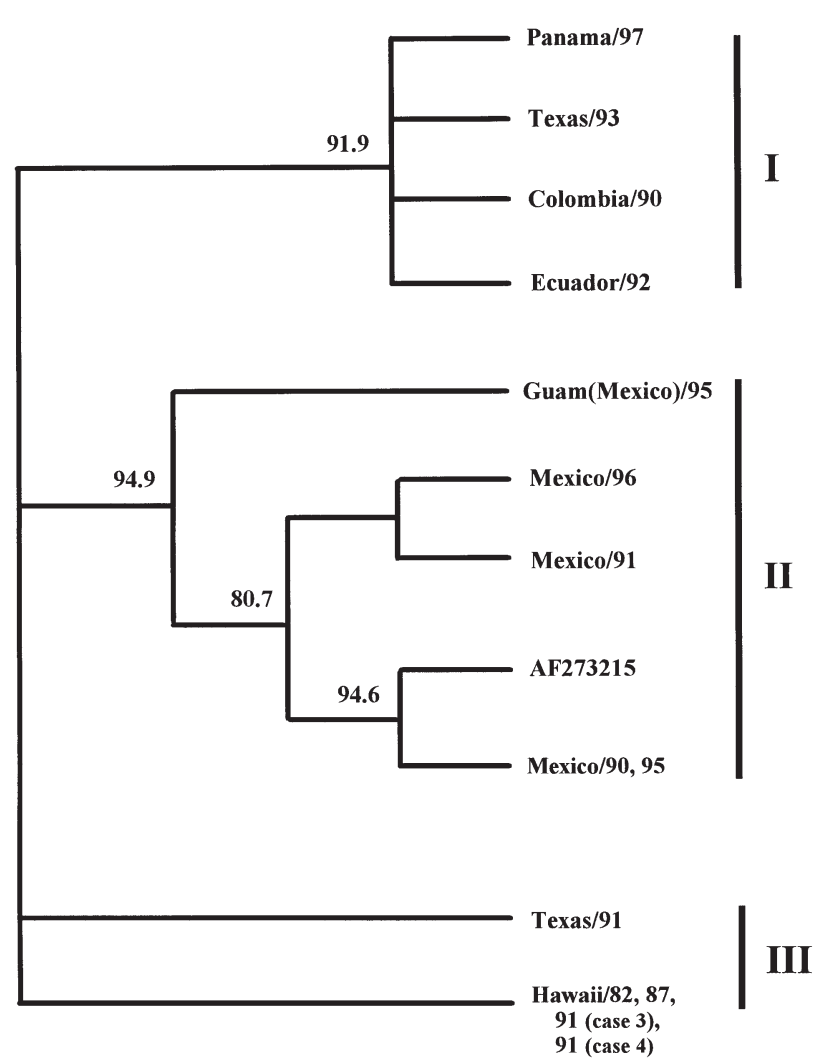

Fig.1. Phylogenetic analysis of $2.9 \mathrm{~kb}$ genomic sequence of 14 IHHNV isolates from Penaeus spp. The analyses were performed with the neighbor-joining (NJ) method in Clustal X. Numbers on branches: percentages of bootstrap support from 1000 replicates, indicated only where support is over $70 \%$. The origin and year of each isolate are also shown

sequences separated the isolates into 3 groups that corresponded well to geographic origin: Central/South America (Group I), Mexico (Group II), and Hawaii (Group III) (Fig. 1). In the grouping of Central and South America isolates (Group I, confidence index = $91.9 \%$ ), 3 isolates were from the farms that are located along the Pacific coast of Panama, Colombia and Ecuador. One Texas isolate (Case 14, 1993) is in Group I, suggesting the origin of this Texas stock was Central or South America.

In the other strongly supported group (Group II, confidence index $=94.9 \%$ ), all the isolates are known to be from Mexico. The Guam isolate falls within this group, its documented origin, but is separated from the isolates from Gulf of California that cluster with a confidence index of $80.7 \%$. An IHHNV sequence deposited in GenBank (Accession No. AF273215; Shike et al. 2000), generated from infected Penaeus stylirostris that were caught from Gulf of California, Mexico, was found, as expected, to be included within this group; this sequence also clustered with 2 other Mexico isolates (Cases 5 and 7, identical sequences) with a high confidence index of $94.6 \%$, suggesting their common origin. Group III contains 4 Hawaii isolates with identical sequences and a Texas isolate (Case 13, 1991). They have extremely close sequence identity (only 1 nucleotide difference). A phylogenetic tree with an identical topology was generated with PAUP and maximum parsimony from 100 replicates (data not shown). These analyses suggest that IHHNV genomic variation is related to geographic origin; however, additional samples are needed to further define the nature of this relationship. The isolates from Hawaiian farms were closer to those from Central or South America (up to $99.93 \%$ similarity) and support the earlier reports that shrimp imported into Hawaii from Central or South America were the routes by which IHHNV was introduced during the early 1980s (Lightner et al. 1983a,b).

In conclusion, we analyzed IHHNV genomesequence variation over the coding region of putative non-structural and capsid proteins. The low sequence variation among isolates collected from 1982 to 1997 indicates that the IHHNV genome has been stable over this time period. This further suggests that the apparent decrease in virulence of IHHNV infection in both wild and cultured shrimp stocks has not resulted from changes in the viral genome. However, we cannot rule out the possibility that changes in other, perhaps regulatory, regions of the genome could have resulted in decreased virulence. Within the IHHNV sequences that were studied, the relatively minor variation among the isolates appears to be related to geographic origin. If indeed the IHHNV genome has remained stable, the reduced virulence could be attributed to the development of a more balanced host-pathogen relationship, as suggested by Morales-Covarrubias et al. (1999).

In 1990, when the landings of Penaeus stylirostris were at their historical low ( $50 \%$ of pre-1990), 32 to $58 \%$ of wild P. stylirostris collected from the Gulf of California were infected with IHHNV, as determined by histology and by in situ hybridization. Pantoja's 1990 study (Pantoja et al. 1999) indicated that the wild stocks of $P$. stylirostris were decimated by IHHNV infection. This was based on the observation that IHHNV was highly virulent to farm-raised P. stylirostris whose parent stocks were derived from wild stocks in the Gulf of California (Lightner et al. 1992). Follow-up studies done at the same sites 6 yr later found that the $P$. stylirostris were still infected with IHHNV but that the landings were returning to pre1990 levels (Morales-Covarrubias et al. 1999). This is consistent with the hypothesis that $P$. stylirostris stocks have become more adapted to IHHNV. Laboratory bioassays also support this hypothesis. In our laboratory from the mid-1980s to the early 1990s, $P$. stylirostris that were challenged with early IHHNV 
isolates (collected from 1982 to 1987) showed very severe mortality (Lightner et al. 1987 and other unpubl. data). However, in recent years (since 1996), challenges of $P$. stylirostris with the same inoculum, which had been stored frozen at $-70^{\circ} \mathrm{C}$, elicited infections with IHHNV but without resulting mortalities. Further studies are planned to investigate this apparent reduction in host susceptibility when specific pathogen-free $P$. stylirostris become available.

Acknowledgements. This work was supported by the Gulf Coast Research Laboratory Consortium Marine Shrimp Farming Program, CSRS, United States Department of Agriculture (USDA), under grant no. 00-38808.

\section{LITERATURE CITED}

Bonami JR, Trumper B, Mari J, Brehelin M, Lightner DV (1990) Purification and characterization of the infectious hypodermal and hematopoietic necrosis virus of penaeid shrimps. J Gen Virol 71:2657-2664

Erdman DD, Durigon EL, Wang QY, Anderson LJ (1996) Genetic diversity of human parvovirus B19: sequence analysis of the vp1/vp2 gene from multiple isolates. J Gen Virol 77:2767-2774

Fox JM, McCrackin Stevenson MA, Bloom ME (1999) Replication of Aleutian mink disease parvoviruses in vitro is influenced by residues in the VP2 protein. J Virol 73: 8713-8719

Flegel TW (1997) Major viral diseases of the black tiger prawn (Penaeus monodon) in Thailand. World J Microbiol Biotechnol 13:433-442

Gallinella G, Venturoli S, Gentilomi M, Musiani M, Zerbini M (1995) Extent of sequence variability in a genomic region coding for capsid proteins of B19 parvovirus. Arch Virol 140:1119-1125

Hemauer A, Poblotzki A, Gigler A, Cassinotti P, Siegl G, Wolf $\mathrm{H}$, Modrow S (1996) Sequence variability among different parvovirus B19 isolates. J Gen Virol 77:1781-1785.

Hillis DM, Bull JJ (1993) An empirical test of bootstrapping as a method for assessing confidence in phylogenetic analysis. Syst Biol 42:182-192

Holthuis LB (1980) Shrimps and prawns of the world: an annotated catalogue of species of interest to fisheries. FAO species catalogue. FAO Fisheries Synpopsis No 125, Vol 1. Food and Agricultural Organization of the United Nations, Rome

Kalagayan G, Godin D, Kanna R, Hagino G, Sweeney J, Wyban J, Brock J (1991) IHHN virus as an etiological factor in runt-deformity syndrome of juvenile Penaeus vannamei cultured in Hawaii. J World Aquacult Soc 22: 235-243

Lightner DV (ed) (1996) A handbook of shrimp pathology and

Editorial responsibility: Carey Cunningham,

Aberdeen, Scotland, UK diagnostic procedures for diseases of cultured penaeid shrimp. World Aquaculture Society, Baton Rouge, LA

Lightner DV, Redman RM, Bell TA, Brock JA (1983a) Detection of IHHN virus in Penaeus stylirostris and $P$. vannamei imported into Hawaii. J World Maricult Soc 14:212-225

Lightner DV, Redman RM, Bell TA (1983b) Infectious hypodermal and hematopoietic necrosis, a newly recognized virus disease of penaeid shrimp. J Invertebr Pathol 42: $62-70$

Lightner DV, Mohney LL, Williams RR, Redman RM (1987) Glycerol tolerance of IHHN virus of penaeid shrimp. J World Aqua Soc 18:196-197

Lightner DV, Williams RR, Bell TA, Redman RM, Perez A LA (1992) A collection of case histories documenting the introduction and spread of the virus disease IHHN in penaeid shrimp culture facilities in Northwestern Mexico. ICES Mar Sci Symp 194:97-105

Mari J, Bonami JR, Lightner DV (1993) Partial cloning of the genome of infectious hypodermal and hematopoietic necrosis virus, an unusual parvovirus pathogenic for penaeid shrimps; diagnosis of the disease using a specific probe. J Gen Virol 74:2637-2643

Morales-Covarrubias MS, Nunan LM, Lightner DV, MotaUrbina JC, Garza-Aguirre MC, Chavez-Sanchez MC (1999) Prevalence of infectious hypodermal and hematopoietic necrosis virus (IHHNV) in wild adult blue shrimp Penaeus stylirostris from the northern gulf of California, Mexico. J Aquat Anim Health 11:296-301

Nunan LM, Poulos BT, Lightner DV (2000) Use of polymerase chain reaction for the detection of infectious hypodermal and hematopoietic necrosis virus in penaeid shrimp. Mar Biotechnol 2:319-328

Pantoja CR, Lightner DV, Holtshmit KH (1999) Prevalence and geographic distribution of infectious hypodermal and hematopoietic necrosis virus (IHHNV) in wild blue shrimp Penaeus stylirostris from the Gulf of California, Mexico. J Aquat Anim Health 11:23-34

Saitou N, Nei M (1987) The neighbor-joining method: a new method for reconstructing phylogenetic trees. Mol Biol Evol 4:406-425

Shike H, Dhar AK, Burns JC, Shimizu C, Jousset FX, Klimple KR, Bergoin M (2000) Infectious hypodermal and hematopoietic necrosis virus of shrimp is related to mosquito Brevidensoviruses. Virology 277:167-177

Thompson JD, Gibson TJ, Plewniak F, Jeanmougin F, Higgins DG (1997) The CLUSTAL-X windows interface: flexible strategies for multiple sequence alignment aided by quality analysis tools. Nucleic Acids Res 25:4876-4882

Tijssen P, Bergeron J, Dubuc R, Hebert B (1995) Minor genetic changes among porcine parvovirus groups are responsible for major distinguishing biological properties. Semin Virol 6:319-328

Truyen U, Gruenberg A, Chang SF, Obermanier B, Veijalainen P, Parrish CR (1995) Evolution of the felinesubgroup parvoviruses and the control of canine host range in vivo. J Virol 69:4702-4710

Submitted: July 19, 2001; Accepted: January 7, 2002

Proofs received from author(s): May 2, 2002 